\title{
42. Plant-Bed with the Cathaysian Flora of Kaizan- tung, Kantô-syô, Manchuria, and Its Relation to the Marine Permian Deposits. II.
}

By Hisakatsu YABE and Rikizô IMAIzUMI.

(Comm. by H. YABE, M. I. A., July 12, 1946.)

Part 1 (Continued)

M. Noda of the Central National Museum of Manchoukuo, Hsinking, reported (Museum Bulletin, No. 6, Dec., 1943), ${ }^{(12)}$ on his observations of the Touman formation in the field covering Kaizan-tung in Kantô-syô and Kamisanbon in North Kankyô-dô. He recognized the following three parts:

Upper division: more than $1,000 \mathrm{~m}$ thick. Dominant rocks: gray clayslate, black shale, black phyllitic clayslate, grayish green small-grained conglomerate, bluish gray sandstone, mica schists; often interbedding hard, compact black sandstone-hornfels and clayslate-hornfels; a gray-bl lish conglomerate at the base, $50 \mathrm{~m}$ thick. A sandstone-hornfels lying upon the conglomerate exposed near Kami-Saisyû-dô contains :- Polypora? sp., Chonetes chonetoides (Chao), Spirifer cf. musakhailensis Davidson, -Spiriferella persaranae Grabau. Spiriferina (Tylotoma) cf. cristata Schlotheim, Pseudomonotis (Aviculomonotis) kazanensis (de Verneuil).

While Noda merely cited the occurrence of these fossils, M. Minato described independently some of the following fossils fon the material collected by T. Nagao from the same locality (those with an asterisk are described).

Fenestella spp., * Polypora manchoukuoensis Minato, Acanthocladia? sp., Batostomella? sp., *Waagenophyllum indicum (Waagen \& Wentzel), *Linoproductus lineatus (Waagen), *Echinorhynchus. sp., * Spiriferina cristata Schlotheim, Spirifer nasuta Waagen, Hustedia sp., Marginifera sp., Aviculopecten sp.

Middle division: $600 \mathrm{~m}$ thick. Upper part mostly consisting of red and green clayslates, chlorite schist. Interbedding small-grained conglo; merate and sandstone of the same colors. Lower part mostly composed of black clayslate and green siliceous clayslate and sandstone, interbedding red clayslate; sometimes with lenticular limestone in the

(12) M. Noda: Bull. Cent. Nat. Mus., Manchoukuo, No. 6, 1943. 

middie.

Lower division: more than 1,000 m thick. Black clayslate, shale, sandstones, hornfels; and dark gray limestone. A limestone in the upper part exposed at Yakusuizi yielded Yabeina hayasakai Ozawa and Waagenophyllum sp., and that of Saisyûrei, Triticites sp., and Wentzelella timorica (Gerth). Another limestone, about $50 \mathrm{~m}$ thick in the lower part exposed at Sekidon yielded, Mizzia velebitana Schubert, Lunucammina? conica Lange, Pachyphloia pediculus Lange, Pachyphloia sp. nov., Staffela sp., Triticites sp., Parafusulina imlayi Dumbar, Parafusulina lungtanensis Chen, Parafusulina cf. constricta Chen, Doliolina spp., Neoschwagerina cf. margaritae Deprat, Sumatrina gemmellaroi Silvestri, Sumatrina sp., Crinoidea, gen. sp. indet.

While an unconformity is expeoted beneath the basal conglomerate of the Upper division, the time-gap it represents may perhaps, as Noda stated, be insignificant, since the upper and lower divisions do not much differ in their respective geological age on faunal evidence.

There are certain discrepancies between the field observations of the junior writer and those of Noda. The lower division of the latter, characterized by two fossiliferous limestone zones, lies outside the area studied by the former, who, however, suspects its contemporaneity with the upper division, bearing in mind that the lithological difference of them is merely due to that of depositional facies. May it be, one thing is certain, namely, the younger complex of the junior writer, of conglomerate with a plant bed, of Kaizantung does not lie in the field of Noda's observation.

Part II. Remarks on the Geological Age of the Plant-Bed.

Recent progress in palaeobtanical researches has revealed that during the late Palaeozoic time, Asia was divided into three botanical provinces, 1) the Angara land with the Kusnezk flora, in the north, 2) the Cathaysia or Sinomalaya land with the Cathaysian or Gigantopteris (s. 1.) flora, in the east and southeast, and 3) India (Gondwana-India) with the Gondwana- or Glossopteris flora, in the southwest.

The northern, late Palaeozoic Kusnezk flora, extending over northern

(13) M. Minato: On the Geological Age of the Toman Formation (in Japanese). Bull. Geol. Inst., Manchoukuo, No. 106, 1942, pp. 47-52. Notes on Some Permian Fossils from the Toman Formation in Southeastern Manchoukuo. Jour. Fac. Sci. Hokkaidô Imp. Univ., Ser. IV, Vol. VII, No. 1,-1943, pp. 49-58.

(1) T.G. Halle: On the Distribution of the Late Palaeozoic Floras in Asia. Geografiska Annaler, 1935, p. 106. 
Asia from Pechora and the Urals to the Japan Sea coast, comprises many elements of the Glossopteris flora and of the European Permian. The precise geological age of it is still unsettled. While $\mathbf{M}$. Neuburg believes it to be partly Upper Carboniferous and partly Lower Permian, M. Zalessky claims the Middle Permian age for the main part and the Lower Carboniferous for the rest.

The Cathaysia- or Gigantopteris flora is that of the Late Palaeozoic coal formations overlying South and North China, South Manchuria and Tyôsen. Its characteristic elements extend far southward to Sumatra and New Guinea. In the Djambi district of Sumatra, W. J. Jongmanns and W. Gothan found Cathaysian floral elements in association with the Euroamerican ones in a formation interbedding a marine horizon with Pseudoschwagerina somewhat below the plant beds. The geological age of the plant beds are Westphalian $\mathrm{E}$ according to the two authors. So far as now known, this is the lowest horizon with the Cathaysian flora.

A discovery of some elements of the Cathaysian flora from a locality of the upper course of the Oetakwa river, south coast of New Guinea, close to a locality with the Gondwana floral s'ements, leads one to expect there an occurrence of both floral elements in association. Whatever be the geological age of the plant bed, the locality is important as it is the southernmost outpost of the Cathaysia in close proximity of the Gondwana land.

The best studied region of the Cathaysian flora is that of the western and eastern Hills of Taigen (Taiyu?n), central Shansi, ${ }^{(5)}$ where the piant-bearing deposits are distributed in two series in succession, namely in ascending order, the Yuehmenkou-, and Shihhotse series, the last mentioned is directly overlain by the Shihchienfeng series in which organic remains are scarese. The Shihhotse is divided into two parts, lower and upper. These two parts are continuous in deposition, but the latter is separable from the former by

(2) M. Neuburg: An Essay of Stratigraphical and Age Subdivision of the Carboniferous Series of Deposits within the Kusnezk Basin in Siberia (Preliminary Report). Bull. Geol. Prosp. Serv., USSR, 1931, Fasc. 5.

(3) W. J. Jongmas und W. Gothan: Reiträge zur Kenntnis der Flora des Oberkarbons von Sumatra. Verh. Geol. Mijnb. Genoot. Nederland en Kolonien, Geol. Ser., VIII, 1925, p. 279-304. W. J. Jongmans: The Flora of the Upper Carboniferous of Djambi (Sumatra, Netherl. India) and Its Possible Bearing on the Palaeogeography of the Carboniferous. Compt. Rend. Deux. Congr. Strati. Carb. 1, 1937, p. 345-362.

(4) W. J. Jongmans: Beiträge zur Kenntnis der Karbonflora von Niederländisch Neu Guinea. Geol. Bur. Heerlèn, Meded., 1938 en 1939, p. 263-274.

(5) T. G. Halle : Palaeozoic Plants from Central Shansi. Pal. sinica, Ser. A, Vol. II, Fasc. 1, 1927. 
the frequent interbedding of sediments of variegated color.

After a detail study of the plant fossils, T. G. Halle conciuded the Stephanian (Uralian) age of the Yuehmenkou series, and Lower Permian age of the Lower Shihhotse. In regard to the Upper Shihhotse with the Gigantopteris flora s. s., he stated that it" may even fail entirely within the Lower Permian, because :

1. The uppermost plant beds of the western and eastern Hills of Taiyuan enclose some typical elements of the Kusnezk flora.

2. The Kusnezk flora is rot younger than the Upper Permian, as beds with Kusnezk flora in the Ussuriland is overlain by marine Lower Triassic deposits with characteristic fauna and Pleuromeia, a very typical plant of the Buntsandstein of Europe."

In this chronological correlation, he was very cautious, obstructed by an earlier view of the seniour writer that the Tikando plant bed of the Kôbôsan series of Tyôsen with a florula somewhat similar to that of the highest plant beds of Shansi may be basal Triassic.

To support his view of the geological age of the Upper Shihhotse, Halle emphasized the late discovery by G. Bexell of plant beds at four horizons in the Richthofen Mountains of the Nanshan region. The stratigraphical order of succession as observed by Bexell at the locality is, in ascending order :(6)

1. Marine sediments with intercalations of plant-bearing beds, about 90 m. Plant-bearing zone A.

2. Predominant green sediments, about $200 \mathrm{~m}$. Plant-bearing zone $\mathrm{B}$.

3. Transition-zone of parti-coloured (green and red) barren sediments, about $150 \mathrm{~m}$.

4. Red, barren sediments, about $450 \mathrm{~m}$.

5. Transition-zone of parti-coloured (green and red) barren sediments, about $150 \mathrm{~m}$.

6. Green sandstones and shales, about $100 \mathrm{~m}$. Plant-bearing zone C.

7. Greenish or reddish, coarse, barren sediments. about $500 \mathrm{~m}$.

8. Green or brownish sandstones with intercalations of black carbonaceous shales, about $300 \mathrm{~m}$. Plant-bearing zone D.

Halle correlated the plant-bearing zone A, with Neuropteris psuedovata, Emplectopteris triangularis, Tingia Hamaguchii and several others to the Yuehmenkou series of Shansi, and the zone B, with Annularia cf. Shirakii,

(6) T. G. Halle: On the Distribution of the Palaeozoic Flora in Asia. L. c. T. G. Halle: The Relation between the Late Palaeozoic Floras of Eastern and Northern Asia. Compt. Rend. Deu Congr. Strati. Carb. Heeren, 1935, 1937, p. 237. 
Sphenophyllum Thonii, Pecopteris cf. orientalis, Callipteris sp., Alethopteris Norinii, Taeniopteris multinervis, $T$. cf. taiyuanensis, Glenopteris Wongii, Lepidodendron oculis-felis, Walchia, Plagiozamites oblongifolius, Tingia carbonica, and many others, to the Lower Shihhotse. The florulas from these zones evidently belong to the Cathaysia flora. On the contrary, the plant-bearing zone $\mathrm{C}$ encloses typical elements of the Kusnezk flora, namely, Phyllotheca deliquescens, $P$. cf. Schtschurowskii, Callipteris aff. Zeilleri, C. murensis, Iniopteris sibirica, Brongniartites cf. salicifolius, Zamiopteris glossopteroides, Rhipidopsis gingkoides, $R$. lobata and Noeggerathiopsis scalprata.

Neuburg distinguished the earlier series I and later series II in the late Palaeozoic Kusnezk stratigraphy, and Callipteris remains occur in the Series II, but not in the Series I. The above mentioned florula of Zone C of the Richthofen Mountains, with Callipteris, Halle stated, approximately corresponds to the Series II of the Kusnezk basin, and further on, "Since that part of the plant-bearing deposits of Kusnezk which thus corresponds to zone $\mathrm{C}$ in Nanshan is universally regarded as Permian, it follows that the later phase of the Cathaysia flora (the upper Shihhotse flora and the Kobosan flora of Shansi and Korea respectively) can not well be Triassic, as is beleived by Japanese authors." "The Gigantoperis-bearing divisions of the Kusnezk flora is either younger than the Upper Shihhotse flora, or its earliest phase corresponds to the latest phase of the latter."

The Upper Shihhotse flora with Gigantoperis nicotianaefolia is the typical Gigantoperis flora s. s., also known as the Gigantopteris nicotianaefolia flora.

Gigantopteris nicotianaefolia itself (or more in general any species of the genus) does not occur in the plant-bearing zones A and B of the Richthofen Mountains. On the other hand, this very species is well represented, according to E. Kon'no, in the Kaizan-tung fossil flora. On the senior writer's request, he kindly forwarded the following note after his preliminary study of its composition and affinity to the Shansi flora.

The Kaizan-tung flora is to be regarded not only as the Cathaysia flora but as the Gigantopteris flora s. s., as it encloses Lobatoannulaxia heianensis and. Gigantopteris nicotianaefolia itself. This correlation finds support in having several types of Rhipidopsis in common with the Kôbôsan flora of Tyôsen. On the other hand, however, there are four species (Sphenophyllum Thonii, S. verticillatum, Pecopteris tuberculata; $P$. cf. candolleana) in the Kaizan-tung florula, which are known from the Upper Zido series, but lacking in either of the Kôbôsan series of Tyôsen and the Tsaichia series(1) of the Tai 
No. 7.] Plant-Bed with the Cathaysian Flora of Kaizan-tung, Kantô-syô, Manchuria.

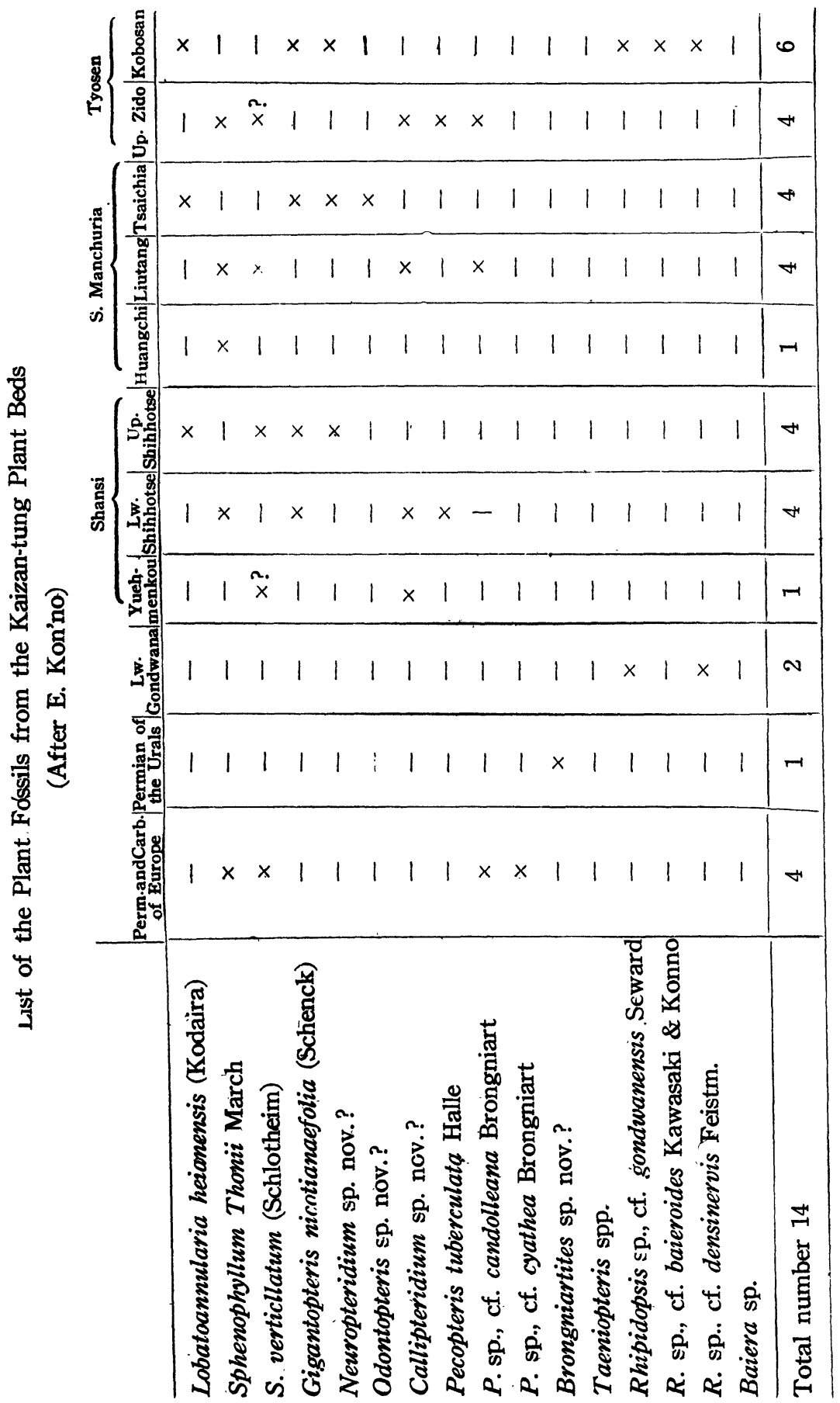


tsuho system of South Manchuria. This goes to show, that the fossil flora in question represents the early half of the Gigantopteris flora s. s., an inference in consonance with the absence of Chiropteris remains in it, which are found in the later half of the Gigantopteris flora s.s., in Tyôsen as well as in Shansi.

Most noteworthy is the presence of a species of Brongniartites in the Kaizan-tung florula. This genus was established by Zalessky on Neuropteris salicifolius from the Upper Permian ( $\mathrm{P}_{\mathrm{r}}$ ) of the Oufa region and the Pechorian $\left(\mathrm{P}_{\frac{1}{2}}\right)$ of the Pechora region. Being not yet known from Siberia, the species an not be regarded definitely as an element of the Kusnezk flora.

So far is the communication from E. Kon'no, for which the present writers are very gratefull.

That Brongniartites salicifolius was lately found by Bexell from his plantbearing zone $\mathrm{C}$ of the Richthofen Mountains in association with several elements of the Angara flora, was already mentioned above- Brongniartites is probably an essential element of the late Palaeozoic Kusnezi flora, as all of its localities known up to date lie in the area of distribution of the Kusnezk flora, though, like the case of Gigantopteris of the Cathaysia flora-Brongniartites probably found its way far into North America, being represented by $B$. ? yakiensis D. White and B. aliena D. White in the Hermit shale of the Grand Canyon, Arizona.(2) The very peculiar Hermit flora was assigned by D. White to a stage near the top of the Lower Permian, hence almost contemporaneous with the Kaizan-tung florula.

Notwithstanding to the conservative view of Kon'no, the presence of a species closely resembling Brongniartites salicifolius, the present writers believe, is suggestive of an intrusion of the Kusnezk elements into the field of the Cathaysian flora.

(1) M. Noda: Studies on the Carboniferous and Permian Formations of Southern Manchoukuo. Jubilee Publ. in Commem. of Prof. H. Yabe's 60th Birthday, 1941, p. 989.

(2) D. White: Flora of the Hermit Shale, Grand Conyon, Arizona, 1929, p. 38. 